\title{
Whack-a-mole: En undersøgelse af falske nyheder og deres økosystemer
}

Daniel Bach, kandidatstuderende ved Techno-Anthropology, Aalborg Universitet; Anders Grundtvig, kandidatstuderende ved Techno-Anthropology, Aalborg Universitet; Ronja Ingeborg Lofstad, kandidatstuderende ved Techno-Anthropology, Aalborg Universitet; Asbjørn Fleinert Mathiasen, kandidatstuderende ved Techno-Anthropology, Aalborg Universitet; Asger Gehrt Olesen, kandidatstuderende ved Techno-Anthropology, Aalborg Universitet; Andreas Birkbak, adjunkt ved Institut for Laring og Filosofi, Aalborg Universitet; Anders Koed Madsen, lektor ved Institut for Loering og Filosofi, Aalborg Universitet; Anders Kristian Munk, lektor ved Institut for Laring og Filosofi, Aalborg Universitet.

Vi argumenterer for, at falske nyheder skal forstås og undersøges empirisk i deres naturlige habitat. Falske nyheder bør ikke blot håndteres som et spil whack-a-mole, hvor formålet er at slå det falske ned, hver gang det dukker op, som var det et muldvarpehoved $i$ en spilleautomat, men derimod at forsøge at forstå de gange, muldvarpen graver.

Introduktion

I forbindelse med kritik af et forslag om at hæve hastighedsbegrænsningerne på de danske landeveje udtalte en politiker for nyligt, at "forskere skal have lov at have deres holdninger i fred, det rokker ikke ved min opfattelse" (Kusnitzoff 2017). Eksemplet er illustrativt for en tendens til, at eksperter ikke har den autoritet, som man måske kunne forvente, at de burde have. Dette er, populært sagt, et godt eksempel på det, der i de seneste år har fået diagnosen 'det post-faktuelle demokrati' (Brun 2015). Sagen er ikke blot en strid om fakta, men om den vægt som fakta i det hele taget bør tillægges, når der skal foretages en politisk afvejning. Derfor er det også problematisk udelukkende at behandle den type situationer som et spørgsmål om at beskytte respekten for sandheden og eksperternes autoritet. For det er naturligvis muligt at have forskellige politiske meninger om færdselslovens indretning, uagtet hvad sagkundskaben måtte anbefale, men hvorvidt og hvordan denne skal tillægges betydning er en problematisk diskussion. Det synes at være debatten om det post-faktuelle demokratis helt store dilemma, og det er et dilemma, der bliver sat ekstra på spidsen, når det drejer sig om fænomenet falske nyheder. Selve begrebet signalerer, at vi kan faktatjekke os til løsninger. Men ofte er sagen den, at et kompliceret økosystem af halve sandheder, politisk spin, særinteresser, decideret videnskabelig 
usikkerhed og politisk propaganda skaber empiriske situationer, hvor en overdreven insisteren på, at faktatjek kan stå alene, skaber nogle blinde vinkler. Falske nyheder er netop præget af at være et buzzword, og det kan være svært at blive enige om, hvad præcis der indkapsler dette begreb. Er der tale om deciderede falske nyhedsartikler, eller kan man inkludere politisk motiveret misinformation og dårlig journalistik? Indkapsler falske nyheder også russisk propaganda og alt-right internet memes?

Begreberne 'postfaktuelt' og 'falske nyheder' hænger sammen i en sådan forstand, at begge dele er en måde at italesætte et allerede eksisterende fænomen, altså propaganda og 'dårlig' viden, særligt på internettet. En søgning på Google Trends viser, hvordan interessen for begge begreber stiger inden for en bestemt uge i november 2016 - samme uge som Præsident Donald Trump bliver valgt i USA (Se figur 1). Begreberne kom for alvor i søgelyset i sidste halvår af 2016, og Oxford Dictionaries kårede endda 'post-truth' som årets ord (Oxford Dictionaries 2016).

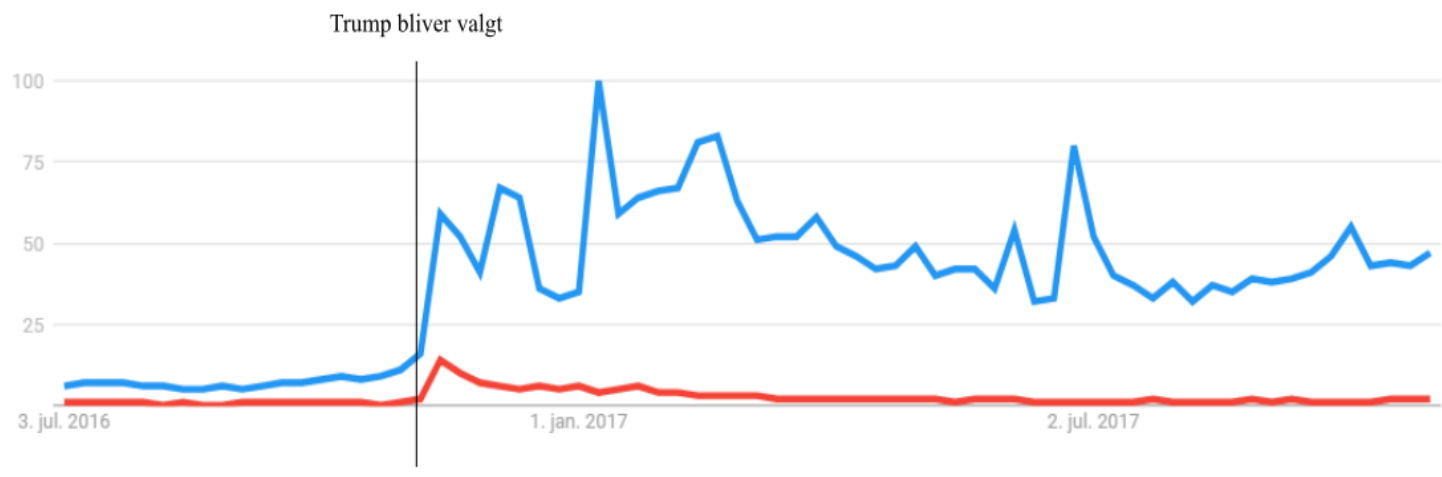

Figur 1 Google Trends giver et normaliseret indblik i søgetermers popularitet over tid. I dette tilfælde er kurverne hhv. 'fake news' (blå) og 'post-truth' (rød). ${ }^{1}$

Uanset om disse fænomener er gammel vin på nye flasker (Darnton 2017), eller om vi reelt har bevæget os fra et faktuelt til et postfaktuelt samfund, så er de en lejlighed til at undersøge empirisk, hvordan falske nyheder cirkulerer online.

Det er en specifik omstændighed, at cirkulationen af falske nyheder ofte kobles til en teori om, at de sociale medier agerer ukritisk agent for deres spredning. Begreber som ekkokamre (Sunstein 2007) og filterbobler (Pariser 2011) er blevet foreslået med det formål at indfange, hvordan sociale medier giver anledning til, at samfundsmæssige diskussioner lukker sig om sig selv. På grund af personaliseret indhold, bliver vi som brugere af nettet ikke eksponeret for modsatrettede holdninger, hvilket gør lommer af relativ ignorance mulige, og nogle gange endda radikaliserer partikulære synspunkter. Vores undersøgelse tyder imidlertid på, at det kan være en forhastet konklusion at forstå sociale medier som mange små bobler af ignorance.

Når en nyhedsartikel bliver stemplet som falsk, siger det ikke blot noget om artiklen og dens afsender, men også en hel del om den institution, der aktivt anvender stemplet.

\footnotetext{
${ }^{1}$ Kilde: https://trends.google.dk/trends/
} 
For hvem har retten til at bestemme, hvad der er sandt og falsk? Som et led i at forstå nyhedsmediers opfattelse af falske nyheder, foretog vi en rundspørge ${ }^{2}$ blandt ansvarshavende ved danske aviser om deres håndtering af, og frygt for, fænomenet. Frygten bliver ikke anset som en direkte trussel mod deres daglige virke, idet samtlige aviser peger på de journalistiske dyder som deres vigtigste redskab til at overkomme problemet med det falske. Hvad disse dyder konkret indeholder eller går ud på, er dog ikke særligt veldefineret.

Imidlertid lader det til, at falske nyheder ofte bliver behandlet på en måde, der udlægger, hvordan indholdet gør nyheden falsk, uden at se nærmere på, hvilken betydning cirkulationen har. Dette relaterer sig også til klassiske studier fra STS, som netop påpeger, at fakta kræver konstruktion og cirkulation for at blive fakta (Latour 1999).

De empiriske undersøgelser af cirkulationen, der ligger til grund for denne artikel, består netop af en undersøgelse af, hvordan cirkulationen af indhold også har indflydelse på opfattelsen af fakta.

I en filosofisk realistisk opfattelse er fakta uafhængige af de systemer, der har produceret dem. Ved udelukkende at fokusere på indholdet isoleret fra dets omgivelser begås netop den kortslutning, at der findes én normativ opfattelse af, hvad der er sandt, uagtet om den er oplyst af journalistiske dyder, videnskabelig redelighed eller doxa. Ligeledes er der risiko for, at det falske opnår en ikke proportional mængde fokus og bekymring, når det bliver hevet ud af de kontekstuelle gange, det har gravet. I denne form for filosofisk realistiske opfattelse er fakta forstået som uafhængige af de systemer, der har produceret dem.

Aktør-netværks teoretiske studier af videnskabelig praksis har søgt at demonstrere, at fakta finder kraft $i$ et fortløbende og møjsommeligt arbejde med at stabilisere de netværk, der opretholder dem. Det er en konstruktivistisk position, der adskiller sig fra relativisme ved ikke at antage, at en gruppe individer blot kan beslutte sig for at tro på alternative fakta. I stedet handler kampen om sandheden i høj grad om evnen til at alliere sig med den materielt-fysiske verden. Et eksempel på dette kan findes i Bruno Latours analyse af den franske videnskabsmand Louis Pasteurs kamp for at få anerkendt mikrober som årsag til sygdom. Når det lykkedes Pasteur at afvise sin videnskabelige modstander Pouchets teori om spontan genese og at stabilisere eksistensen af mikrober som et videnskabeligt faktum, skal forklaringen hverken findes $i$, at mikrober findes, og ergo er et faktum (filosofisk realisme), eller $i$ at en gruppe mennesker kollektivt valgte at tro på deres eksistens (socialkonstruktivisme). Forklaringen skal findes i det bevisets teater som Pasteur og hans allierede lykkedes med at stable på benene (Latour 1988). Den samme analyse med afsæt i alliancen med den materielt-fysiske verden, der gør sig gældende i analysen af Pasteur og Pouchet, kan med fordel appliceres på diskussionen omhandlende falske nyheder. For at forstå de forhandlinger om den sandfærdige opfattelse af nyheder stemplet som falske, er det altså vigtigt både at undersøge de materielt-fysiske

\footnotetext{
${ }^{2}$ Rundspørgen blev udført som led i en præliminær undersøgelse for at få en forståelse af medielandskabets opfattelse af falske nyheder. Forfatterne foretog uformelle samtaler med journalister og redaktører ved Danmarks Radio, Information, Radio 24/7, Politiken, Ritzau og Ekstra Bladet.
} 
begivenheder, som sagen drejer sig som, så vel som de sociale dynamikker, der gør sig gældende i relationen mellem artikel og læser. Det er dette komplekse aktør-netværk, som består af alle involverede instanser, både de materielle og de sociale, der afgør, hvordan falske nyheder lever, trives og bliver accepteret i samfundet.

Den normative opfattelse - hvis man kan tale om sådan én - af indhold og fakta, afgøres således ikke udelukkende på baggrund af en målbar sandhed, men også i høj grad ud fra et netværk af argumenter, følelser, aktører og tilhørsforhold. Når det kommer til falske nyheder, er der altså tale om en form for journalistisk gråzone, hvori der ikke hersker enighed om, hvad der konstituerer sandheden.

De falske nyheders cirkulation og livscyklus eksisterer på baggrund af, hvad Bruno Latour kalder 'matters of concern' (Latour 2004). Et 'concern' forstås som en konstruktion af holdninger, magtpositioner og fakta, der konstituerer en given aktørs holdning til en sag. At noget er et 'matter of concern' indikerer netop, at en specifik sag, genstand eller fænomen er til debat. Dette kan i høj grad siges at være tilfældet med hensyn til falske nyheder, da disse kun er relevante i kraft, at nogen tror på, at de falske nyheder er sande. Hermed ikke sagt, at man bør overgive sig til total relativisme i arbejdet med de falske nyheder.

\section{Det empiriske fundament}

Det empiriske arbejde, der ligger til grund for denne artikel, er udført ved tre uge-lange datasprints, to i København og ét i Amsterdam, i foråret 2017. De tre datasprints blev faciliteret under det interdisciplinære kollaborativ Public Data Lab, der inkluderer forskere fra en lang række europæiske forskningsenheder, der arbejder med digitale metoder og kontroversstudier (Munk et. al. 2017), herunder TANT-Lab ved Aalborg Universitet $\mathrm{CPH}$, médialab ved Sciences Po Paris og Digital Methods Initiative ved University of Amsterdam.

Under en datasprint samles forskere, fagpersoner med specifik viden om feltet, der undersøges, og dataeksperter omkring et givent emne med det formål at udrette noget hurtigt sammen (Munk et. al. 2017). Ved at have områdespecifik viden til stede og give den en aktiv stemme i forskningsspørgsmål får vi mulighed for at komme tæt på studieobjektet og ikke blot på afstand at kritisere forhold uden empirisk basis.

De empiriske cases, der fremlægges i denne artikel, er hver især et resultat af en bekymring eller undren hos en fagperson, der til dagligt har en berøringsflade med falske nyheder - samt en række tilknyttede ressourcer, der er i stand til at oversætte denne undren eller bekymring til et forskningsspørgsmål og at undersøge dette online ved hjælp af diverse værktøjer og analyseredskaber. De fagpersoner, vi har arbejdet med i projektet, har alle været praktiserende journalister eller medieforskere. 


\section{Muldvarpejagt}

Én reaktion, som er blevet eksponeret i den offentlige debat, er behandling af falske nyheder som en form for mangel på viden i de offentligheder, der findes på blandt andet sociale medier. Dette kan blandt andet ses i Facebooks samarbejde med en række faktatjek-initiativer, hvor en advarsel popper op på skærmen, når man forsøger at slå artikler op, som er i blevet debunked af en af disse faktatjek-initiativer.

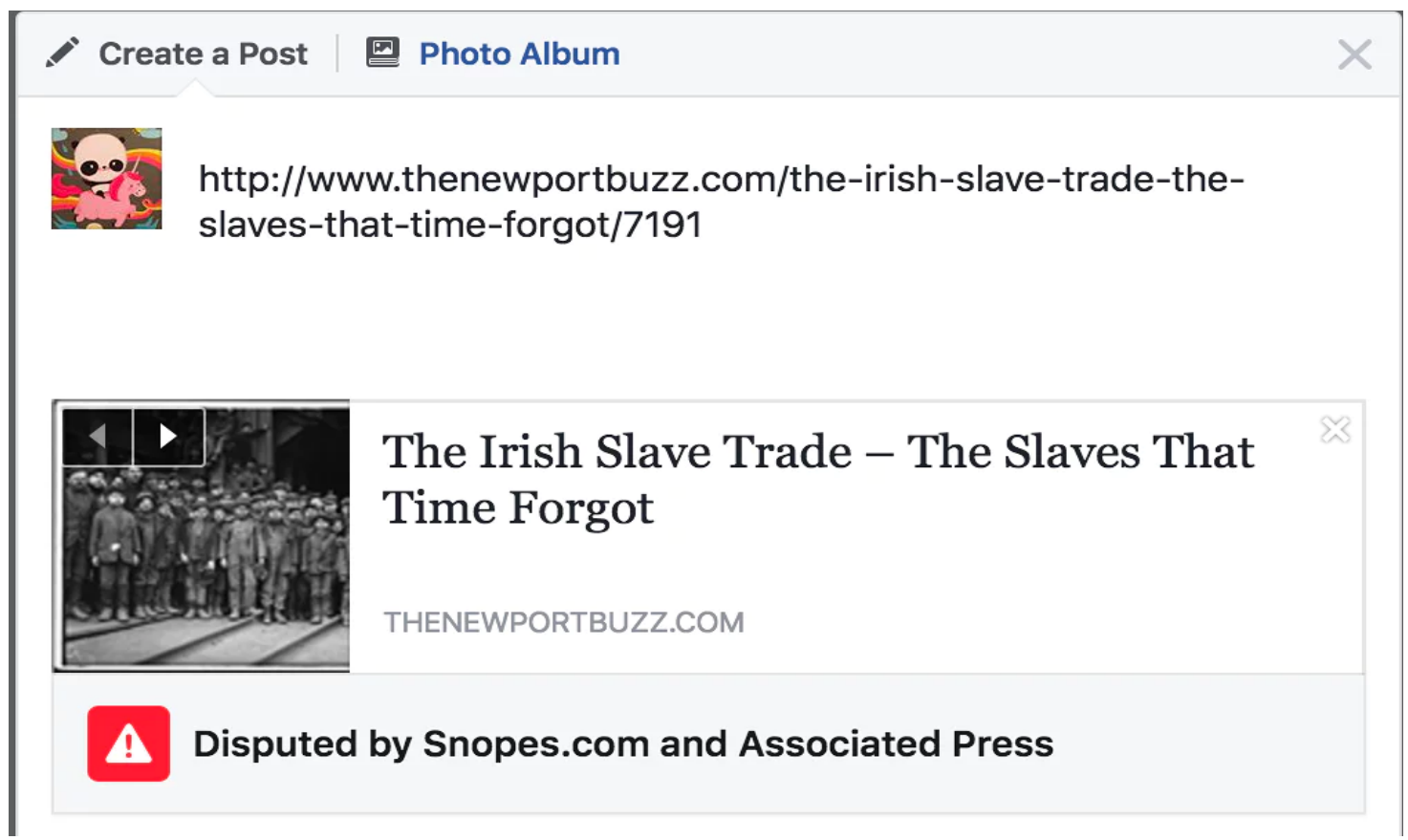

Figur 1: Eksempel på en artikel som har fået mærkatet "Disputed by" på Facebook (Hunt 2017).

Hvis man skal følge dette ræsonnement, findes der bobler af uvidenhed, hvor vi skal tilføre noget sand viden. Det er dermed diverse sandhedsautoriteter såsom medier mv., der får til rolle at identificere, hvad der er sandt eller falsk. Særligt engagerede i falske nyheder er de såkaldte faktatjek-initiativer, som gør det til deres hovedopgave at skrive artikler, som modbeviser påstande, falske nyheder m.m. At skabe overordnede kategorier for, hvad der er sand viden, og hvad der er falsk viden. Hvis vi skulle føre vores metafor videre, ville det være at skelne muldvarper, som er de falske nyheder, fra mosegrise, som er de sande nyheder.

Forskellen, set fra vores videnskabsteoretiske muld, er nærmere orienteret imod at forholde sig til den måde, hvorpå aktørerne i de forskellige cases selv refererer og kategoriserer, hvad der er vigtigt. Dermed påtager vi os ikke at afgøre, hvad der er vigtigt, før vi har undersøgt det empirisk, og aktørerne har udfoldet sagen (Marres 2015).

Grundtanken bag faktatjek-initiativerne er at oplyse offentligheden om, hvorvidt en nyhedsartikels indhold er sandt eller falsk. Faktatjek-hjemmesider som Snopes ${ }^{3}$ bygger

\footnotetext{
${ }^{3} \mathrm{http} / /$ www.snopes.com/ er en hjemmeside, der, da den blev skabt, behandlede vandrehistorier.
} 
på Whack-a-mole-mentaliteten, hvor der anvendes et sandheds-meter, som rangerer artiklers indhold på en fempunkts-skala fra 'true' til 'false'. Snopes er bl.a. partner i en tilføjelse til Facebook, hvor brugerne får besked, hvis de er ved at dele indhold, som Snopes anser som værende falsk.

En måde at behandle falske nyheder på i akademia er igennem tanken om holdningsøkonomier (Hendricks \& Hansen 2014, 85-100), som bliver koblet op på begreber om bobler. Det er en sammenligning mellem markeds-bobler, og hvad forfatterne kalder holdningsbobler. Såfremt holdninger er et marked, og der er en uoverensstemmelse mellem udbud, som er mulige holdninger, og efterspørgsel, som er folk, der skal overbevises om en holdning, kan der ske en overophedning af markedet. Det kan i så fald ende med, at de falske informationer får en betydelig større vurdering end deres reelle værdi, og der skabes derved en såkaldt holdningsboble (Hendricks \& Hansen 2014, 85-100). Alt dette hviler selvfølgelig på, at man aktivt bruger og vurderer, hvordan begreber som sandt og falsk operationaliseres. Eller sagt på en anden måde, at sandt og falsk endegyldigt kan defineres.

Umiddelbart virker holdningsøkonomier tillokkende som tilgang. Vi låner vores tilgang til, hvordan man kan behandle falske nyheder fra Marres, som bl.a. benytter de to begreber demarcationist approach og empiricist approach (Marres 2015).

I relation til den demarkationistiske tilgang gælder, at man som forsker deltager i at sortere, hvilke typer informationer der er sande og falske. Dette er f.eks. det som faktatjekinitiativer benytter - altså at 'eksperter' sorterer i, hvad der er sande nyheder, og hvad der er falske nyheder.

Til forskel for denne tilgang har de undersøgelser, som ligger til grund for denne artikel, benyttet sig af en empiristisk tilgang (Marres 2015). Når vi kan situere udsagn, værktøjer, medier og andre aktører i relation til det specifikke område, tillader det, at der bliver stillet helt andre spørgsmål ved at kortlægge infrastrukturer omkring debatten vedrørende falske nyheder.

Der har allerede været nogle studier, der har søgt at afdække fænomenet fake news fra en empirisk tilgang. De fleste eksisterende tilgange (Qiu et. al. 2017, Jin et. al. 2014, Alcott \& Gentzkow 2017, Jin et. al. 2013) forklarer fake news gennem epidemiologisk modellering. Det vil sige at se fake news som en smitsom virus, der smitter uvidende individer med misledende information.

\section{Muldvarpens gange}

I vores studier af falske nyheder forsøger vi at arbejde med et agnostisk princip om generaliseret symmetri (Callon 1984, 2). Vores mål er at kortlægge, hvad aktører opfatter som sandt og falsk, og behandle det på lige fod ud fra empiriske studier. Måden, hvorpå vi arbejder med falske nyheder og symmetriprincippet, er ved at kortlægge kontroversen $i$ det miljø, hvori den huserer. Dette er i de falske nyheders tilfælde online på hjemmesider og sociale medier. Det er her, at det omkringliggende miljø og andre aktører i 
kontroversen, stempler nyheden som 'falsk' frem for at definere nyhedens karakter på forhånd og dekontekstualisere den. Netop dette budskab om at studere de falske nyheder i deres eget økosystem danner det metodiske grundlag for dette forskningsprojekt. Metodisk benytter vi os af objektivitet i anden grad (Venturini 2012, 3). Dette handler om at benytte aktørernes repræsentationer af selve temaet eller striden. Venturini (2012) definerer det således: "2. grads objektivitet handler om at tildele hver aktør en repræsentation der passer dens position og relevans i striden" (Venturini 2012, 3, Forfatternes oversættelse)

Paven støtter Trump

Et projekt fra datasprinten i Amsterdam (Public Data Lab 2017) undersøgte en historie om, at Pave Frans efter sigende skulle have bakket op om daværende præsidentkandidat Donald Trump i forbindelse med det amerikanske valg i 2016. Ved at følge cirkulationen af en nyhed fra medie til medie sætter vi os selv i en position, hvor vi får mulighed for at forstå nyhedens forskellige stadier og udvikling frem for udelukkende at forstå den gennem 'likes' og 'delinger'. Som led i dette projekt fulgte vi, ved hjælp af Google siderangering og dokumentanalyse, hvilke artikler der skrev om historien, og hvilke kilder de anvendte. Google håndterer 77 procent af alle de søgninger, der finder sted online (Richter 2017), og de fleste artikler, der bliver læst, er tilgængelige gennem Google. Måden, hvorpå at undersøgelsen blev foretaget, var med manuel kodning, hvor der blev genereret en generisk søgeterm til Googles søgemaskine i incognito mode, der skulle omfavne artikler relateret til den undersøgte case. I dette tilfælde var søgetermen 'Pope Endorses Trump' (Public Data Lab 2017, 59-76). Resultaterne blev efterfølgende kodet med følgende karakteristika: Resultat $n r, I D, U R L$, dato, estimeret dato, overskrift, genre, debun$\mathrm{ked}^{4}$, side type, omtalt som rigtig, omtalt som falsk, linket kilde, kopieret tekst fra kilde, skiftende emne, kommentar. Efter kodningen kan resultatet samles og netværket formes i et netværkskort. Det sker ved, at alle linkede artikler enten gennem URL eller gennem kopiering af tidligere kilder bliver samlet på en tidslig akse, der i dette projekt viser udviklingen af en historie. Denne metode giver et billede af henholdsvis en nyhedsartikels tidligste spor online, hvordan den cirkulerede, før den blev kaldt falsk, og hvad der sker efter, den får dette mærkat.

Vi kan bruge netværkskortet til at dykke ned i specifikke artikler og undersøge forfatteren nærmere, eller undersøge hvordan og hvor den undersøgte artikel eksisterer på sociale medier.

\footnotetext{
${ }^{4}$ Afsløret som falsk
} 


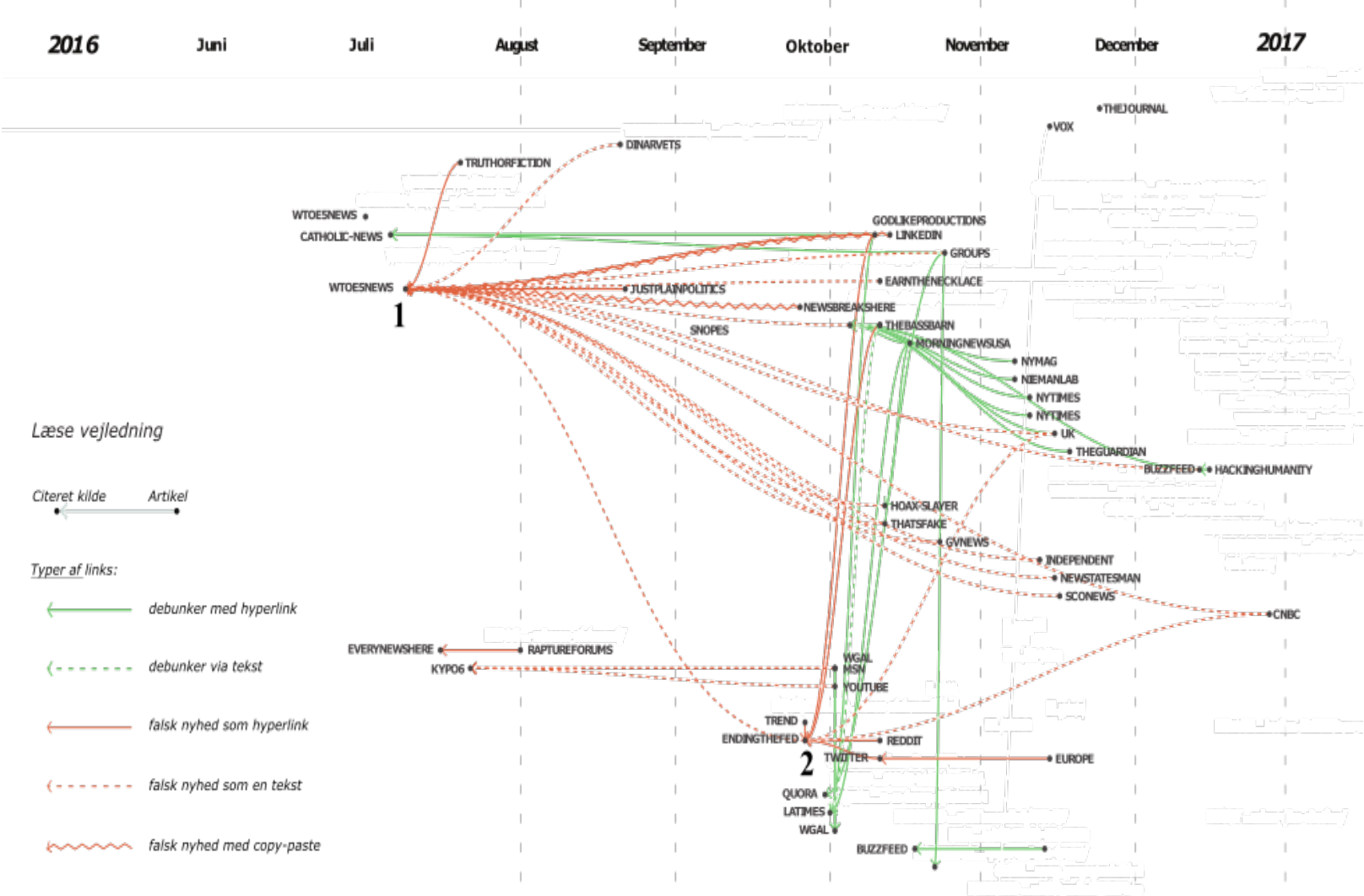

Figur 2: Visualisering af citationer omhandlende 'Pope endorses Trump'. Prikkerne indikerer artikler, orange streger indikerer citationer, der behandler historien som sand, grønne streger indikerer artikler, der behandler historien som falsk. Om linjerne er stiplede eller faste indikerer, henholdsvis, hvorvidt artiklen citerer en kilde eller kopierer indholdet fra den oprindelige kilde.

Af figur 2 kan vi se, hvordan nyheden om, at Paven støtter Trump rejser i de digitale rum. Tallet 1 viser den originale selverklærede satiriske artikels udgivelse i juli 2016. Artiklen får herefter kun ganske lidt cirkulation i de efterfølgende tre måneder. Tallet 2 viser tidspunktet, hvor historien bliver samlet op og 'hvidvasket' af hjemmesiden Endingthefed ${ }^{5}$. Historien bliver præsenteret som værende sand uden at nævne, at den originalt kommer fra en satire-hjemmeside. Denne hvidvaskning og præsentation som sand er katalysator for en eksplosion i historiens cirkulation. Historien bliver både afsløret som falsk (debunked) af mange større og etablerede medier samt reproduceret som sand af en række medier på højrefløjen i USA.

Vi kan med dette netværk overskue, hvor artiklen fødes, og hvornår den dør ud igen. Netværket viser altså ikke, hvor mange der læser og deler artiklen, men giver et indtryk af, hvor mange forskellige platforme artiklen eksisterer og rejser på. De platforme, der har højest Googles siderangering, bliver vurderet til at have den største udbredelse,

\footnotetext{
${ }^{5}$ http://endingthefed.com/
} 
og det er derfor relevant at forstå, hvordan forskellige sider citerer hinanden. Hvis man kun interesserer sig for delinger og likes på sociale medier, mister man forståelsen af, at en nyhed aldrig eksisterer som ét objekt, der rejser rundt $\mathrm{i}$ et netværk, men at nyheden derimod konstant bliver genfødt $\mathrm{i}$ forskellige former og farver. Historiens rejse rundt $\mathrm{i}$ netværket foregår ikke udelukkende med links til tidligere artikler. De falske nyheder opstår på ny uden links, og det er umuligt at få et samlet overblik udelukkende igennem sider som Facebook.

Efter at have kortlagt nyhedens cirkulation kan vi nu spørge, hvordan den opstod og ligefrem hvorfor. Vi kan undersøge, hvordan spredningen kronologisk foregår, og hvordan nyheden mobiliserer mennesker og medier. Om Paven støttede Trump eller Hillary er irrelevant. Interessant er det, at historien om, at Paven støttede Trump, gik viralt og eksisterede samtidigt både som sand og falsk i dens levetid. Vi ser på kortet, at nyheden fødes som satire, bliver taget op som noget, der ligner clickbait for så at blive debunked af flere forskellige medier nogenlunde samtidigt, hvilket får cirkulationen til at eksplodere: nyheden begiver sig nu på sin livsrejse til forskellige afkroge af internettet.

Dette eksempel viser hvordan en historie bliver mobiliseret som falsk i løbet af dens livscyklus - hvordan den kan opstå, og hvordan den bevæger sig - og at medier, der debunker, ikke altid formår at mobilisere nok troværdighed til at mane falske historier i jorden.

\section{Acceleration af cirkulation}

At undersøge falske nyheders cirkulation kan også i nogle tilfælde give indblik i, hvad der gør, at en nyhed bliver en viral nyhed. En anden undersøgelse fra Amsterdam, der fulgte samme metode, omhandlede en falsk nyhedshistorie, der beskrev, at den daværende franske præsidentkandidat Emmanuel Macron var homoseksuel. Dens rejse gennem internettet er visualiseret i figur 3.

Tidlig i nyhedens livscyklus (nr. 1) bringer to sider en nyhed om, at Macron er homoseksuel. Et halvt år efter (nr. 2) skriver enkelte sider artikler, der afviser påstanden, men uden at referere til de tidligere artikler. I december 2016 sker der en eksplosion i antallet af sider, der rapporterer om Macrons seksuelle orientering. Nyheden bliver taget op i et russisk nyhedsmedie, Russia Today ${ }^{6}$ (nr. 3), der skriver, at Macron er homoseksuel. På dette tidspunkt bliver nyheden rekontekstualiseret fra at være en tilfældig påstand til at blive et udtryk for russisk misinformation. Det er denne rekontekstualisering, der skaber den kraftige reaktion (mellem nr. 3 og 4), hvor blandt andre de større franske nyhedsmedier engagerer sig i sagen. At alle prikkerne til højre på kortet er grønne (nr. 4), kan ses som et udtryk for, at en konsensus blev nået om, at det er en falsk nyhed, at Macron er homoseksuel.

\footnotetext{
${ }^{6} \mathrm{https}: / /$ www.rt.com/
} 


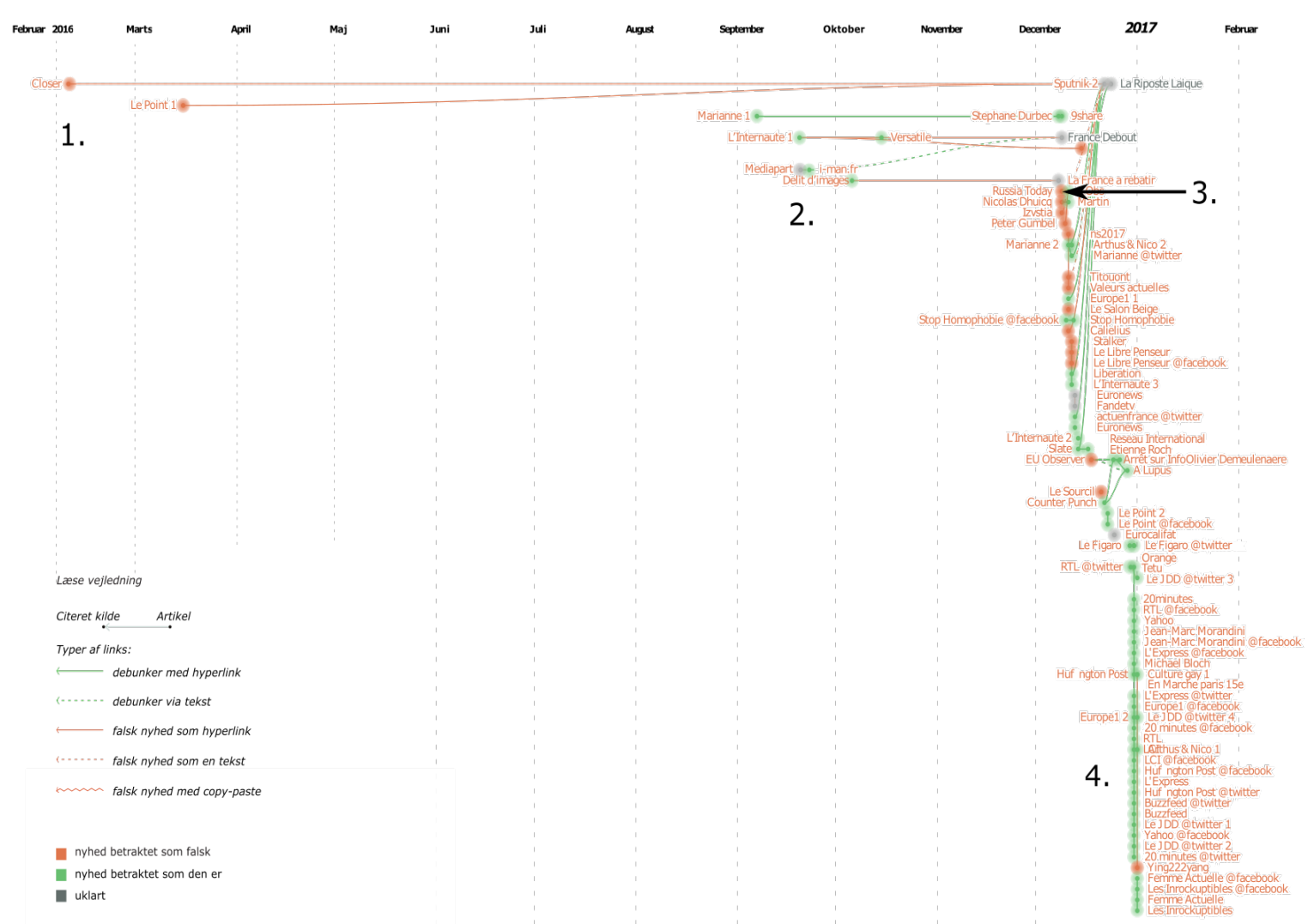

Figur 3: Visualisering af citationer omhandlende "Macron Gay". Prikkerne indikerer artikler, orange streger indikerer citationer, der behandler historien som sand, grønne streger indikerer artikler der behandler historien som falsk. Om linjerne er stiplede eller faste indikerer, hvorvidt artiklen citerer en kilde eller kopierer indholdet fra den oprindelige kilde.

Ingen af de nyheder, vi har fulgt, er gået viralt uden først at leve et længere liv i internettets undergrund. Det er gennem en ændring i rammesætning, indhold eller kontekst, at nyhederne pludselig opnår massiv opmærksomhed.

\section{En muldvarp med flere ansigter}

Googles siderangering kan anskues som et udtryk for, hvor populær og relevant en hjemmeside er i forhold til andre. Dog giver siderangeringen os ikke et direkte billede af, hvordan cirkulationen forekommer på de sociale medier. Ser vi nærmere på, hvordan og med hvilket ansigt de falske nyheder spreder sig over de sociale medier, ser vi et andet eksempel på, at nyheder kan sprede sig som en sandfærdig nyhed på trods af, at en debunking har fundet sted.

I en anden case undersøgte vi med hvilket ansigt, nyheden cirkulerede. Nyheden handlede om en afrikansk milliardær, der tilbyder afrikanere en sum penge for at forlade 
USA og vende tilbage til Afrika. Vi fandt, at nyheden ikke blot cirkulerer enten som debunked eller som sandfærdig nyhed, men også at den debunkede version cirkulerer som en sandfærdig nyhed. På billedet nedenfor ser vi en liste over de nyhedssider, der modtog mest trafik om den specifikke historie (figur 4). Der regnes på henholdsvis daglige besøgende, hvor længe de besøgende bruger på siden, søgemaskiners rangering og hvor mange, der linker til den givne hjemmeside.

Vi kan se, at Snopes' udgave af artiklen placerer sig på en andenplads i forhold til disse kriterier, og at Snopes-artiklen bliver eksponeret som værende sand. Det er først, hvis den besøgende åbner artiklen, at det fremgår, at artiklen er en debunking.

Denne nyhed fulgte det samme mønster som de tidligere eksempler. Et halvt år senere blev nyheden omformuleret til, at den afrikanske milliardær ville støtte tilbagerejse, hvis Trump blev proesident. I denne form blev nyheden én af de mest delte falske nyheder under det amerikanske valg (Public Data Lab 2017, 22-23).

African Billionaire Will Give $\$ 1$ Million To Anyone Who Wants To Leave America if Donald Trump is Elected President $\pitchfork$ Save

jewsnews.co.il - More from this domain

By Admin - Nov 14, 2016

Article

African Billionaire Will Give $\$ 1$ Million to Anyone Who Wants to Leave America If Donald

Trump Is Elected President : snopes.com $\downarrow$ Save

snopes.cem - More from this domain

By Bethania Palma - Nov 11, 2016

article

African Billionaire Will Give $\$ 1$ Million To Anyone Who Wants To Leave America if Donald

Trump is Elected President $\pitchfork$ Save

officialdasentonline.com - More from this domain

Nov 4, 2016

Article

African Billionaire Will Give $\$ 1$ Million To Anyone Who Wants To Leave America if Donald

Trump is Elected President $\$ Save

horndiplomat.com - More from this domain

By Horn Diplomat - Nov 6, 2016

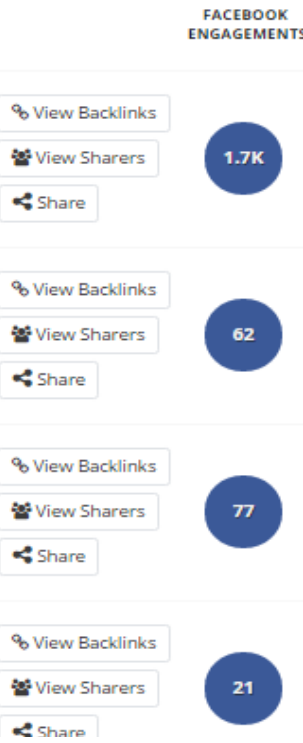

Figur 4: Oversigt over de nyhedssider, der modtog mest trafik for deres artikler om, at en afrikansk milliardær vil give penge til dem, der vil forlade USA, hvis Trump bliver valgt til præsident.

\section{De sociale medier}

Artiklers delinger og likes på sociale medier kan umiddelbart virke nemt at beregne og derigennem være en nem indikator for artiklens spredning og betydning. Dog skal man både være opmærksom på, at spredning ikke er direkte oversætteligt til troværdighed, og at selve måden disse delinger og likes bliver optalt varierer alt efter, hvilken metode mediet benytter. Alene på f.eks. Facebook møder vi forskellige opgørelser alt efter hvilken beregningsmetode, der benyttes. Der er forskel på, om Facebook medregner hyperlinks som delinger, eller om man som bruger skal have trykket på delingsknappen, før de tæller med i statistikken. Denne forskel ses, når man sammenligner en artikels delinger på Facebook genereret af antal klik på delingsknappen med det antal gange, artiklens URL 
optræder på Facebook ${ }^{7}$. At de sociale medier ikke er direkte oversættelige og gennemsigtige som forskningsplatform er en kendt faktor, som forskere, der benytter netop denne platform til udgangspunkt for sin undersøgelse, skal være bevidste om (Marres 2012; Birkbak og Munk 2017). Men eftersom at det blandt andre steder er på de sociale medier, at de falske nyheder har deres livscyklus, insisterer vi på at foretage vores undersøgelse netop her.

\section{Facebook-diskussioner}

En historie, der modtog opmærksomhed i en dansk kontekst, var nyheden om, at den tidligere præsident af USA, Barack Obama, sendte 3.600 kampvogne mod den russiske grænse dagene før, han skulle afgå som præsident. Nyheden fødes, da et russisk medie, Doni News, lancerer historien (DONi News Agency 2017). Herfra bliver historien samlet op af et kommunistisk canadisk medie, hvorfra den bl.a. spredes til Danmark via KPnet, en kommunistisk politisk side, der oversætter historien til dansk (Chossudovsky 2017). Herfra rejser den bl.a. via Facebook, hvor forskellige enkeltpersoner deler nyheden, hvormed små individuelle grupperinger på Facebook uafhængigt af hinanden begynder at diskutere nyheden.

Forholder man sig udelukkende til antal delinger, kan man via Facebook-appen Netvizz (Rieder 2013) erfare, at KPnet udgaven er blevet delt 1.293 gange. Denne information fortæller hverken, hvor bredt historien er kommet ud, eller i hvilket omfang den bliver modtaget med tillid eller mistillid. De 20 Facebook opslag, vi fulgte, blev alle delt med tillid til, at nyheden var sandfærdig. Kigger vi et niveau dybere ned i diskussionerne, tegner der sig dog et langt mere differentieret billede.

Vi analyserede kvalitativt hver enkelt af disse 20 diskussioner og kodede de holdninger, der kom til udtryk ud fra, om aktørerne i diskussionerne har tillid eller mistillid til KPnets udlæg af historien om de 3.600 kampvogne. Vi kodede manuelt med variablerne; Nummer, URL, navn, tidspunkt, trovardighed til artiklen (false or true), racistisk kommentar (false or true), omtaler nyheden (false or true), antal likes, passiv debunking (false or true) og kommentar. Denne kodning blev visualiseret som et 'scatter plot' i RawGraph (Mauri et. al. 2017)

Kigger vi eksempelvis på diskussionstråd 9 bliver nedenstående argumenter benyttet. Person 1 begynder diskussionen med at dele historien med følgende kommentar: "Hvis dette virkelig har noget på sig, så er det jo den mest hjernedøde handling af en afgående præsident, nogensinde”. Dette bliver fulgt op af person 2, der viser mistillid til historien: "Mon dog ikke det havde været i Breaking news, hvis der var hold i det". Person 1 svarer på denne kommentar nu med større mistillid til historiens troværdighed: "Lad os håbe det er en and. Men intet af dette når nyhedsmediet forsider. Mainstreammedierne dækker det simpelthen ikke." Person 3 tager nu del i diskussionen og skriver: "Den er

\footnotetext{
${ }^{7}$ Genereret via Facebook-appen Netvizz (Rieder 2013)
} 
god nok. Det er nyhedsstof i Tyskland. Herhjemme er Obama jo stadig en engel. Og Trump er den krigsgale." Herefter blander 16 andre sig i diskussionen, der løber over de efterfølgende fire dage, hvor historien internt i diskussionen bliver mødt med både tillid og mistillid.

På figur 5 er diskussionerne illustreret. Hver række på y-aksen viser forskellige diskussioner, hvor den første prik i hver række er opslaget, der kommenterer på KPnetartiklen om de krigsparate 3.600 kampvogne. De første prikker er alle røde, hvilket viser, at kommentarerne har tillid til artiklen. Følger vi rækken fra den første prik ud af X-aksen ændrer diskussionerne farve til grøn, hvilket viser kommentarer, der har mistillid til artiklen.

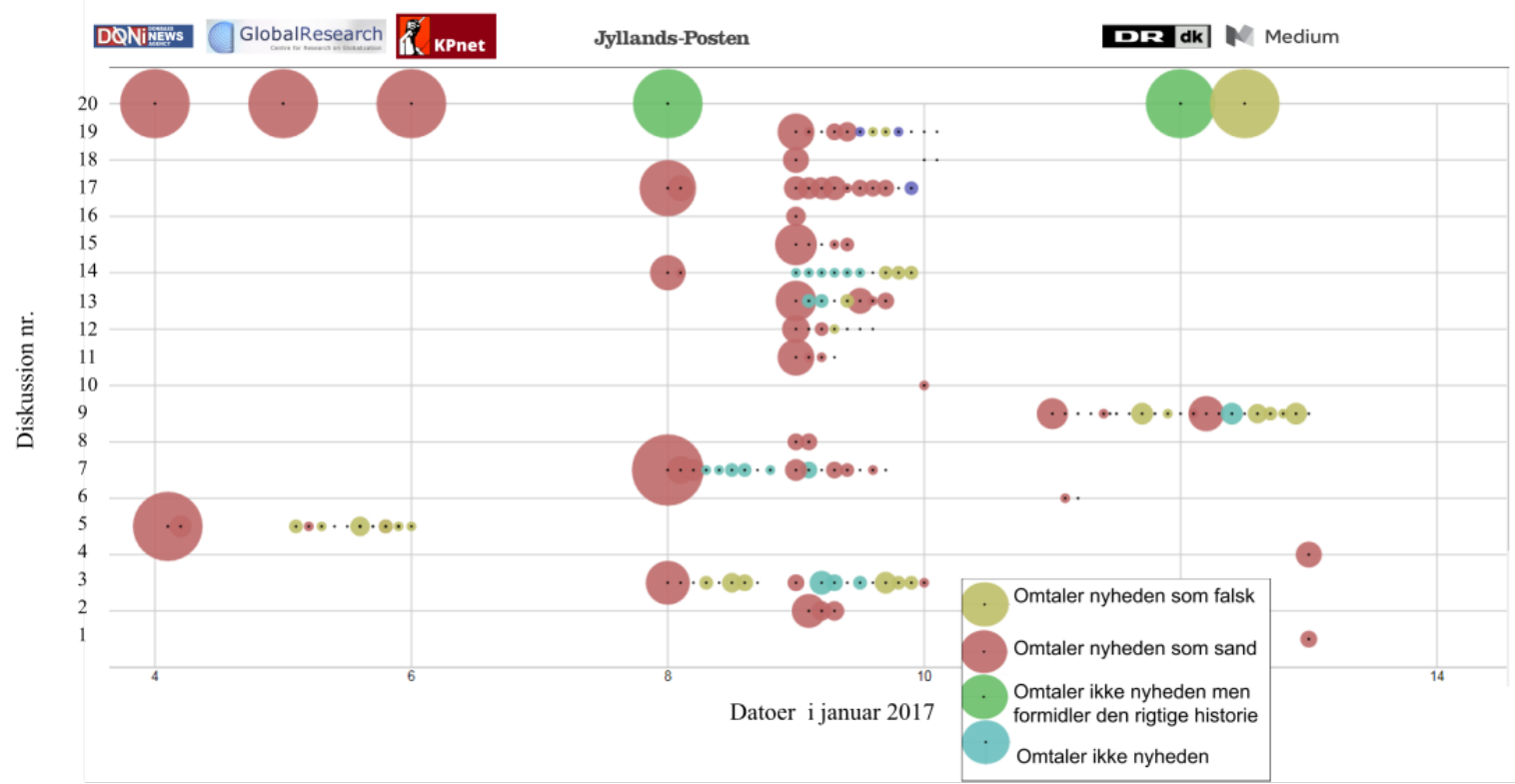

Figur 5: Illustration af Facebook diskussioner. Hver række på y-aksen viser forskellige diskussioner, hvor den første prik i hver række er opslaget, der kommenterer på KPnetartiklen om de krigsparate 3.600 kampvogne. Størrelsen indikerer antal delinger på facebook.

Filterboble-teorien ville argumentere for, at der i hver diskussion ville opstå ensartede argumentationer og fortællinger, der som en spiral ville munde ud i nye sandheder uafhængigt af det omkringliggende samfunds sandheder. I denne case finder vi eksempler på dette, hvor f.eks. to diskussioner hurtigt konkluderer, at Barack Obama blot er en, citat: “dum neger". Men denne case viser også tydelige tegn på reflekterede diskussioner. For at springe lidt i kronologien kan det afsløres, at hovedparten af diskussionerne faktisk ender i diskussioner, der omhandler mediets troværdighed og til sidst ender ud med en kritisk holdning til artiklens troværdighed.

Dykker vi ned i en diskussion og ser på, hvordan den udfolder sig, møder vi ikke kun simpel argumentation med for og imod. Et interessant eksempel er igen diskussion nummer ni. Her ender aktører i diskussionen med at validere deres argumenter igennem artikler fra DR og Jyllandsposten. Interessant ved dette er både, at aktørerne henter 
ekstern information ind i diskussionen, og at den information, de trækker ind, ikke er en debunked udgave af historien, men andre historier omhandlende samme emne. Historien om de 3.600 kampvogne er nemlig, som vi ofte ser det med falske nyheder, opbygget af elementer af begivenheder, der har fundet sted, hvor enkelte dele bliver overdrevet eller opfundet i sådan en grad, at historien kan blive kategoriseret som falsk. Historien om de 3.600 kampvogne er en historie om tropper, der ganske rigtigt var på vej mod den russiske grænse - dog uden 3.600 kampvogne, som KPnet-historien fortæller.

Som diskussionerne på Facebook tager form, ser vi, at aktørerne benytter sig aktivt af artikler fra større nyhedsmedier som DR og Jyllandsposten til at debunke KPnets historie og kalde den utroværdig. Denne handling, hvor artikler, der ikke direkte selv debunker nyhederne, men bliver brugt af aktører til at debunke med, kalder vi passiv-debunking. Passiv-debunkning er altså her situationen, hvor DR og Jyllandsposten har skrevet troværdige artikler, der hverken nævner KPnet eller andre medier, der proklamerede de 3.600 kampvogne, men simpelthen ved at skrive artikler om faktiske situationer kan bruges af aktører i diskussionerne på Facebook. DR-artiklen behandler samme emne som KPnet-artiklen, idet begge artikler omtaler de samme militære styrker på vej mod den russiske grænse, dog uden at referere til hinanden.

Passiv-debunking er her interessant af flere forskellige årsager. Det viser, at aktørerne skaber meninger og altså sandheder, der tydeligt er præget af resten af den omkringliggende omverden, og det skaber ikke unødvendig opmærksomhed til KPnet $i$ et forsøg på at debunke deres historie. En decideret debunking af KPnet her foretaget af Zetland (Mchangama 2017) optræder først næsten en måned efter, at Facebook-diskussionerne hver og især er nået frem til deres egen debunking af historien ved hjælp af delvis logik og dels ved den passive-debunking.

\section{Konklusion}

Vi mener, at vi ved at kortlægge falske nyheder i deres naturlige habitat kan komme nærmere, hvordan falske nyheder cirkulerer, og i hvilken grad de gør det. Falske nyheder har biografier, og de er vigtige at forstå. Nogle, som i eksemplet med Paven der støtter Trump, er startet som satire-historier, andre er halve sandheder, der har fået et politisk spin, mens andre igen er decideret misinformation spredt for at opnå monetære eller politiske mål. Det væsentlige ved at lave denne undersøgelse er at vise, at de falske nyheder ændrer sig over deres livscyklus. Mange forskellige aktører med mange forskellige interesser, bidrager til at puste liv i de falske nyheder. Når dette står klart, bør det også stå klart, at faktatjek ikke altid er den eneste saliggørende måde at behandle falske nyheder på. Det giver ikke meget mening at faktatjekke satire-mediet Rokokoposten.

Falske nyheder eksisterer ikke som den enkelte nyhed afsendt af en enkelt aktør, men som en konsekvens af cirkulationen frem for indholdet. I vores studier fulgte vi adskillige nyheder og så, hvordan de skiftede ansigt og medie. Når muldvarpejagten træder 
ind, og alverdens medier starter kapløbet om at være den første til at debunke, er det $\mathrm{i}$ virkeligheden netop her, at den falske nyhed får adgang til at grave nye gange og udbygge netværket. Kigger vi eksempelvis på Snopes, hvis fineste selvudråbte opgave er at debunke historier, viser vores undersøgelser, hvordan nyheden ikke blot cirkulerer som en debunked historie, men også begynder at cirkulere som den oprindelige historie. Værre er måske, at selv efter at Snopes har udført deres debunking-job, cirkulerer nyheden igennem Snopes på Facebook, hvor det eneste, der er synligt for den hurtige Facebook-bruger, er en nyhed, der er falsk, men ikke kommer til udtryk som falsk. Vi ser dermed, at den falske nyhed nu cirkulerer både i sin oprindelige form på sit oprindelige medie (i sit naturlige habitat) og igennem Snopes. En fremtrædende opdagelse, vi gjorde i vores forskningsprojekt, handler altså om de nye aktører, der bliver en del af cirkulationen af en nyhed og mediedækning.

Vi er i kraft af vores empiriske studier af falske nyheder af den klare overbevisning, at vi er nødsaget til at studere de gange, muldvarpen graver, frem for at slå den i hovedet, når den kigger op over overfladen. Som forskere må vi forstå, hvad begrebet falske nyheder empirisk dækker over frem for eksempelvis at bruge begrebet som begrundelse for valgresultater, vi ikke kan forstå på anden vis. Vores undersøgelse handler om at forstå det netværk af gange, som muldvarpen graver i sit naturlige habitat, hvor nyhederne har deres livscyklus - altså i newsfeed på de sociale medier, i Googles søgeresultater og på obskure hjemmesider uden andre besøgende end dem, der er blevet henvist dertil fra de sociale medier og Google-søgninger.

Som der er afdækket i A Field Guide to Fake News (Public Data Lab 2017), er det ikke en værdiforladt og neutral øvelse at faktatjekke. Når man skal formalisere faktatjek i konkrete praksisser, opdager man de potentielle blinde vinkler, der er ved de forskellige tilgange. Snopes bruger f.eks. en tilgang, hvor materialet bliver bedømt af et udvalg af redaktører. Heri kan der ligge problematikker omkring, hvilke redaktører der vælges, og hvad der er det rigtige spørgsmål at stille som redaktør. Yderligere 'tagges' artikler fx på Snopes, og disse tags bliver valgt af redaktørerne. Dermed er det deres kategorisering af nyheder, der kommer til at bestemme, hvilken type materiale selve nyheden skal kategoriseres som. Den måde at ordne materialet på betyder også noget, hvis man vælger at skelne mellem faktatjek af satire og fake news. Dette kan betyde, at visse typer materiale såsom artikler om Donald Trump bliver proportionelt overrepræsenteret i kategorien fake news.

Gennem studiet af falske nyheder i deres naturlige omgivelser undersøges, hvordan muldvarpen fra platform til platform får nye karaktertræk. Når en nyhed fødes, enten på en obskur eller en etableret hjemmeside, eksisterer denne nyhed ikke som en afgrænset entitet. Den formerer sig, ændrer udseende og formes hurtigt til at omfavne og spredes til diverse hjemmesider og diskussioner på sociale medier. Den bliver opbrudt og eksisterer som dele af andre artikler og som udgangspunkt for nye artikler. Når vi følger cirkulationen af en nyhed i dens eget habitat, den online infrastruktur hvor den bor, følger vi altså ikke længere kun en enkelt muldvarp. Vi følger de underjordiske gange, der er blevet udgravet i muldvarpens og dens afkoms livscyklus. Dette ses tydeligt i vores empiriske 
arbejde med historierne Pope endorses Trump og Macron gay. Historierne lever i relativt lang tid et liv uden at tilegne sig særligt meget fokus, og det er netop i kraft af de første muldvarpes afkom, at historierne føres videre med nye karaktertræk til nye habitater. Undersøger man udelukkende den enkelte muldvarp isoleret fra dens habitat, lange gange, afkom og forfædre, tages historien med andre ord ud af kontekst, hvilket medfører, at en stor del af forståelsen for dens ophav går tabt.

Der er måske ikke enighed om, hvem der med rette kan tildele mærkater som "sandt" og "falsk". Med andre ord: Til trods for at fænomenet 'falske nyheder' bliver brugt til at understøtte idéen, om at vi lever i et postfaktuelt samfund, hvor sandhed som koncept ikke længere giver mening, har den empiriske behandling af fænomenet i medier og i offentligheden i stor grad bidraget til at underbygge dikotomien mellem sandt og falsk. Med dette udgangspunkt er falske nyheder noget af det mindst postfaktuelle, der er sket i mediebilledet i nyere tid.

\section{Litteratur}

Allcott, H. og Gentzkow, A. (2017). Social Media and Fake News in the 2016 Election. Journal of Economic Perspectives, årg. 31(2), s. 211-36.

Birkbak, A. og Munk, A. (2017). Digitale metoder. København: Hans Reitzels Forlag. Brun, A. (2015). Vincent Hendricks: Vi kan ende i "det postfaktuelle demokrati”. RAESON. Tilgængelig på: http://raeson.dk/2015/vincent-hendricks-vi-kan-ende-i-detpostfaktuelle-demokrati-hvor-sandhed-er-ligegyldig-saa-laenge-du-kan-saettesoesaette-robuste-narrativer/ [Tilgået 08.03.18].

Callon, M. (1984). Some Elements of a Sociology of Translation: Domestication of the Scallops and the Fishermen of St Brieuc Bay. The Sociological Review, årg. 32(1), s. 196-233.

Chossudovsky, M. (2017). Politisk vanvid: Obama sender 3.600 tanks mod den russiske grænse. KPnet. Tilgængelig på: https://kpnet.dk/2017/01/06/politisk-vanvidobama-sender-3-600-tanks-mod-den-russiske-graense/ [Tilgået 02.10.17].

Darnton, R. (2017). The True History of Fake News. The New York Review of Books. Tilgængelig på: http://www.nybooks.com/daily/2017/02/13/the-true-history-offake-news/ [Tilgået 04.10.17].

DONi News Agency (2017). US sends 3,600 tanks against Russia - Massive NATO deployment underway. DONI Donbass International News Agency. Tilgængelig på: $\mathrm{https}$ :/dninews.com/article/us-sends-3600-tanks-against-russia-massive-nato-deployment-underway [Tilgået 01.10.17].

Hendricks, V. og Hansen, P. (2014). Infostorms: How to Take Information Punches and Save Democracy. New York: Copernicus. 
Jacomy, M., Girard, P., Ooghe-Tabanou, B. og Venturini, T. (2016). Hyphe, a curationoriented approach to web crawling for the social sciences. I: Proceedings of the Tenth International AAAI Conference on Web and Social Media (ICWSM 2016). Præsenteret ved ICWSM 2016.

Jin, F., Dougherty, E., Saraf, P., Cao, Y., og Ramakrishnan, N. (2013). Epidemiological modeling of news and rumors on Twitter. Proceedings of the 7th Workshop on Social Network Mining and Analysis - SNAKDD 13.

Jin, F., Wang, W., Zhao, L., Dougherty, E., Cao, Y., Lu, C., og Ramakrishnan, N. (2014). Misinformation Propagation in the Age of Twitter. Computer, årg. 47(12), s. $90-94$.

Kusnitzoff, J. (2017). Forskere trætte af debat om højere fartgrænser: Jo, flere vil dø! Videnskab.dk. Tilgængelig på: http://videnskab.dk/kultur-samfund/forskere-traette-af-debat-om-hoejere-fartgraenser-jo-flere-vil-doe [Tilgået 03.10.17].

Latour, B. og Woolgar, S. (1979). Laboratory Life. Princeton: Princeton University Press.

Latour, B. (1988). The pasteurization of France. Cambridge, Mass.: Harvard University Press.

Latour, B. (1999). Pandora's hope. Cambridge, Mass.: Harvard University Press.

Latour, B. (2004). Why Has Critique Run out of Steam? From Matters of Fact to Matters of Concern. Critical Inquiry, årg. 30(2), s. 225.

Mauri, M., Elli, T., Caviglia, G., Uboldi, G., og Azzi, M. (2017). RAWGraphs: A Visualisation Platform to Create Open Outputs. I: Proceedings of the 12th Biannual Conference on Italian SIGCHI Chapter (s. 28:1-28:5). New York, NY: ACM.

Marres, N. (2012). The Redistribution of Methods: On Intervention in Digital Social Research, Broadly Conceived. The Sociological Review, årg. 60(1_suppl), s. 139165.

Marres, N. (2015). Why Map Issues? On Controversy Analysis as a Digital Method. Science, Technology, \& Human Values, årg. 40(5), s. 655-686.

Mchangama, J. (2017). Lad os bekrige de falske nyheder. Første træk: Forstå, hvordan de virker. Zetland. Tilgængelig på: https:/www.zetland.dk/historie/sOKVXID6aevmJ36a-9698d [Tilgået 01.10.17].

Munk, A., Meunier, A. og Venturini, T. (2017). Data Sprints: A Collaborative Format in Digital Controversy Mapping. I: D. Ribes og J. Vertesi (red). Digital STS: A Handbook and Fieldguide. Princeton: Princeton University Press.

Oxford Dictionaries (2017). Oxford Dictionaries Word of the Year 2016 is... Oxford Dictionaries. Tilgængelig på: https://www.oxforddictionaries.com/press/news/2016/12/11/WOTY-16 [Tilgået 02.10.17].

Pariser, E. (2011). The Filter Bubble: How the New Personalized Web Is Changing What We Read and How We Think. New York: Penguin Books.

Public Data Lab (2017). A Field Guide To Fake News. Public Data Lab. Tilgængelig på: https://fakenews.publicdatalab.org/download/SAMPLE-field-guide-to-fakenews.pdf [Tilgået 31.09.17]. 
Qiu, X., F. M. Oliveira, D., Sahami Shirazi, A., Flammini, A. og Menczer, F. (2017). Limited individual attention and online virality of low-quality information. Nature Human Behaviour 1, artikel nummer 0132

Richter, F. (2017). Infographic: 1.17 Billion People Use Google Search. Statista Infographics. Tilgængelig på: https://www.statista.com/chart/899/unique-users-of-search-engines-in-december-2012/ [Tilgået 13.10.17].

Rieder, B. (2013). Studying Facebook via data extraction: the Netvizz application. I: Proceedings of the 5th Annual ACM Web Science Conference. Paris, s. 346-355.

Sunstein, C. (2007). Republic.com 2.0. Princeton: Princeton University Press.

Hunt, E. (2017). 'Disputed by multiple fact-checkers': Facebook rolls out new alert to combat fake news. The Guardian. Tilgængelig på: https://www.theguardian.com/technology/2017/mar/22/facebook-fact-checking-tool-fake-news\#img-1 [Tilgået 30.01.18]

Venturini, T. (2009). Diving in magma: how to explore controversies with actor-network theory. Public Understanding of Science, årg. 19(3), s. 258-273.

Venturini, T. (2012). Building on faults: how to represent controversies with digital methods. Public Understanding of Science, 2årg. 1(7), s. 796-812. 